\title{
Proximate and Mineral Nutrition of Common Bean Genotypes as Influenced by Harvesting Time
}

\author{
Onkgolotse G. Moatshe-Mashiqa ${ }^{1}$, Patrick K. Mashiqa ${ }^{1} \&$ Odireleng O. Molosiwa ${ }^{2}$ \\ ${ }^{1}$ Department of Agricultural Research, Gaborone, Botswana \\ ${ }^{2}$ Department of Field Crops and Horticulture, National Agricultural Research and Development Institute, \\ Gaborone, Botswana \\ Correspondence: Onkgolotse G. Moatshe-Mashiqa, Department of Agricultural Research, Private Bag 0033, \\ Gaborone, Botswana. E-mail moatsheonkgolotse@gmail.com
}

Received: July 12, $2021 \quad$ Accepted: August 10, $2021 \quad$ Online Published: December 15, 2021

doi:10.5539/jas.v14n1p85 URL: https://doi.org/10.5539/jas.v14n1p85

\begin{abstract}
Common bean is the most consumed legume by humans and hence significant for global food security and nutritive value mainly iron (Fe) and zinc $(\mathrm{Zn})$. The objective of the study was to evaluate the effect of harvesting time and genotypes on proximate and mineral composition of common bean. Two field experiments were carried out in Sebele $\left(24^{\circ} 33^{\prime} \mathrm{S}, 25^{\circ} 54^{\prime} \mathrm{E}\right.$, $994 \mathrm{~m}$ above sea level) horticultural fields during summer 2018/2019. Treatments included two common bean genotypes DAB 564 (white) or 520 (red) and three harvesting stages as the early, mid and late season harvest. In both seasons, genotype and harvesting time significantly $(\mathrm{P}<0.05)$ influenced proximate, macro and micro mineral composition of common bean seeds. Generally genotypes studied had a sufficient amount of proximate and mineral content with crude protein, iron (Fe) and zinc ( $\mathrm{Zn}$ ) content as the most abundant minerals at a range between $20-22 \%, 33-101 \mathrm{mg} \mathrm{g}^{-1}$ and $41-45 \mathrm{mg} \mathrm{g}^{-1}$, respectively across harvesting times. Genotype DAB 564 (white coloured) significantly $(\mathrm{P}<0.05)$ produced seeds with the highest concentration of proximate and mineral contents especially zinc $\left(45 \mathrm{mg} \mathrm{g}^{-1}\right)$ and iron $\left(70 \mathrm{mg} \mathrm{g}^{-1}\right)$ content irrespective of season. Harvesting common bean seed early or mid-stage produced high seed concentration of proximate, micro and macro mineral content across genotype or season.
\end{abstract}

Keywords: common bean, genotypes, harvesting time, zinc, iron, crude protein

\section{Introduction}

Legumes are staple food in human diets around the world (FAOSTAT, 2010; Ndidi et al., 2014), hence their wide cultivation in most countries with total world production rates of more than 17 million tonnes, led by China, Indonesia, India and Turkey as the largest producers and consumers of beans (FAOSTAT, 2010; Richardson, 2012). Among legumes, Phaseolus vulgaris (common bean) is highly adaptive, it is drought, heat tolerant and thrives well in marginal soils. Nutritionally, beans are one of the best non-meat sources of iron providing 23-30\% of daily recommended levels from a single serving. Maruapula and Novakofski (2010) has reported iron as the only micronutrient with the intake above the recommended two-thirds of recommended daily allowance (RDA) above making common beans a vital source of iron. Common bean is also rich source of protein, carbohydrates and vitamin B complex with high level of other micro nutrients such as copper, zinc, phosphorus, potassium, magnesium and calcium, high fibre content and a good source of poly unsaturated fatty acids (Kelly \& Scot, 1992; Ndengwa et al., 2006).

Despite the nutritional value of legumes including common bean, most African countries including Botswana still experience high incidences of food insecurity, hunger and micronutrient induced malnutrition including zinc and iron deficiencies (Nestel et al., 2006). In Botswana, 29\% of children below 5 years have impaired growth and $11 \%$ are underweight (UNICEF, 2009). This resulted with 78 million USD of money spent annually for treating vitamin and mineral deficiencies and/or illnesses (UNICEF, 2004, 2009; World Bank, 2009). Also the adult age groups of men and women has poor health conditions which are mostly caused by low macro and micro nutrient intake especially protein, fiber, iron and zinc (Maruapula \& Novakofski, 2010). In Africa, South Africa and Botswana has been reported to have iron deficiencies especially on the elderly groups due to consumption of food which do not meet the daily recommended allowances. Maruapula and Novakofski (2010) reported low micronutrient intake of $\mathrm{Fe}\left(8 \mathrm{mg} \mathrm{day}^{-1}\right), \mathrm{Zn}\left(8-11 \mathrm{mg}\right.$ day $\left.^{-1}\right)$ and selenium for men and women in 
Botswana which may affect the immune system. The adequate iron intake in most health groups especially the elderly was from beef and sorghum grain with low contribution from fruits and vegetables (Maruapula \& Novakofski, 2010). This defieciency incidence is more prominent in infants below 5 and woman and can lead to ailments such as anemia, mental impairment, still births, underweight in infants, blindness and infant mortality. Common bean has been reported to be advantageous for use in the biofortification programs since the baseline grain fe content is high at $55 \mathrm{ppm}$ and variability for the trait is great (Petry et al., 2015).

Besides the food security and health nutritional deficiencies in Botswana, low cultivation rates is also affected by low erratic rainfall, poor soils, high temperatures and droughts. This requires cultivation of hardy crops such as common bean which has an adaptive potential, soil improvement properties and good nutritive value. Studies has reported a wide genetic diversity and variability in growth habit, seed size, shape and colour, maturity and adaptation among common bean genotypes impacting growth, seed yield, quality and nutritional composition (Jones, 1999; Beebe et al., 2000; Tryphone \& Nichumbi-Msolla, 2010). The success of seed filling is a great determinant of seed yield, quality and nutrition as influences timing and duration of a crop to reach physiological and harvest maturity. The visual indicator for the time of harvest is usually predicted by the colour of pods from green to yellow or brown (Cerna \& Beaver, 1989) and may proceed until the pods are completely dry to shattering (Muasya, 2001). Thus legumes attain maximum seed weight at physiological maturity after which drying begins and seed quality indicators begin to deteriorate depending on the time of harvest (Muasya, 2001; Tekrony \& Egli, 1997). Harvest maturity of legumes varies depending on moisture content from $15-20 \%, 19 \%$, $17-25 \%$ and $35-58 \%$ for soybean (Copeland \& McDonald, 1995), mung bean (Dharmaligam \& Basu, 1990), dry bean (Van de Venter et al., 1996; Kelly, 1988) and common bean (Muasya, 2001), respectively. The variation in seed filling time and duration between and within a common bean crop results with concurrent and/or progressive harvesting intervals of common bean seeds hence inconsistency in the seed quality (Muasya, 2001). Simultaneous harvest as practiced by most farmers results in poor seed bulk quality and nutrition (Muasya, 2001; Wortmann, 2006). Therefore this study seeks to assess the seed nutritional concentration among common bean genotype harvested at different stages to establish their optimum time of harvest. The study will determine the nutritive potential of common bean genotypes under Botswana conditions to address the nutritional and health deficient population through evaluating the effect of genotype and harvesting time on proximate and mineral composition.

\section{Materials and Methods}

\subsection{Location}

Field experiments were conducted in Sebele $\left(24^{\circ} 33^{\prime} \mathrm{S}, 25^{\circ} 54^{\prime} \mathrm{E}, 994 \mathrm{~m}\right.$ above sea level) horticultural fields in summer 2018 and 2019. The climate in Sebele is semi-arid with an average annual rainfall (30 year mean) of 558 $\mathrm{mm}$ (Bekker \& de Wit, 1991). Most rain falls in summer, which generally starts in late October and continues to March/April. The mean rainfall ranges between $250-650 \mathrm{~mm}$ per annum. The soils are shallow, ferruginous tropical soil, mainly consisting of medium to coarse grain sandy loams with a low water holding capacity.

\subsection{Experimental Design}

The experiment was laid in a randomised complete block design (RCBD) under split-plot arrangement with three replications. The treatments were two common bean genotypes DAB 564 (white coloured) and DAB 520 (red coloured) allocated randomly to main-plots. These genotypes were selected among Andean common bean (Molosiwa et al., 2019). Three harvesting intervals of early (70 days after sowing (DAS)), mid (80 DAS) and late (90 DAS) season harvest were randomly allocated as subplots. The main plot size will be $3 \mathrm{~m} \times 3 \mathrm{~m}$.

\subsection{Cultural and Management Practices}

The land was cleared, ploughed followed by disc harrowing to a fine soil tilth before planting using mould board and disc harrow. Soil was sampled to determine mineral composition prior to planting. The fertilizer application rates for basal dressing were done according to the soil mineral content after soil analysis. Common bean seed was sown directly, 2 seeds placed per seeding point. All necessary management practices including fertilizer application, pests, disease and weed control were undertaken to enhance good growth and development.

\subsection{Data Collection: Proximate and Mineral Analysis}

Common bean seeds will be harvested at different harvesting times during ripening to determine their proximate and mineral content.

\subsubsection{Dry Matter (DM)}

Dry Matter (DM) content was determined according to method 973.18 of the AOAC (2012), through weighing 
approximately $1 \mathrm{~g}$ of each ground sample into pre-weighed crucibles and placing it in an oven at $60^{\circ} \mathrm{C}$ for 24 hours. DM was calculated as the difference between initial sample weight and moisture weight and expressed in percentage.

\subsubsection{Crude Fibre (CF)}

Crude Fibre (CF) content was determined by the Weende method (AOAC, 1990), through hydrolysing dried samples with boiling $0.128 \mathrm{M}$ sulphuric acid, followed by boiling in $0.223 \mathrm{M}$ potassium hydroxide solution in hot extractor. The residue was washed with preheated distilled water before being transferred to a cold extractor and washed with acetone. The residue and crucibles were oven dried at $105{ }^{\circ} \mathrm{C}$ overnight and weighed $\left(\mathrm{W}_{1}\right)$ before being ignited into a muffle furnace at $450{ }^{\circ} \mathrm{C}$ for $8 \mathrm{hrs}$. The residual ash was first cooled in an oven at $105{ }^{\circ} \mathrm{C}$ overnight, then cooled to room temperature in a dessicator and weighed $\left(\mathrm{W}_{2}\right)$. The percentage of crude fibre was calculated as:

\subsubsection{Crude Protein (CP)}

$$
\% \text { Crude Fibre }=\left[\left(\mathrm{W}_{1}-\mathrm{W}_{2}\right) / \mathrm{W}_{0}\right] \times 100
$$

The ground dry sample was digested in a BD block at $330{ }^{\circ} \mathrm{C}$ for $7 \mathrm{hrs}$. After digestion nitrogen (N) was determined through distillation and titration using the micro kjeldahl method number 976.06 (AOAC, 2012) and then converted to crude protein content through multiplying percentage $\mathrm{N}$ content by a factor of 6.25 and expressed in \%.

\subsubsection{Ash Content}

A finely ground dry sample was weighed into a clean dried crucible which was initially weighed as $\mathrm{W}_{1}$. The sample was ignited over a low flame to char the organic matter with lid removed. The crucible was then placed in a muffle furnace at $600{ }^{\circ} \mathrm{C}$ for $6 \mathrm{hrs}$ until its completely ashed. Thereafter the sample was transferred into the desiccators, cooled and weighed immediately as $\mathrm{W}_{2}$. The percentage ash was calculated as:

$$
\% \text { Ash Content }=\left[\text { Weight Loss }\left(\mathrm{W}_{2}\right) \times 100\right] / \text { Weight of Sample }\left(\mathrm{W}_{1}\right)
$$

\subsubsection{Mineral Analysis Determination}

The samples will be oven-dried at $66{ }^{\circ} \mathrm{C}$ to constant weight ( 72 hours). The dried samples were ground using a sieve of size two and $1.25 \mathrm{~g}$ composite sample used digestion. Digestion was done for 3 hours using One Touch Technology oven (MARS). After digestion of samples N, P, K, Na, Ca, mg, Zn and Fe will be determined. Nitrogen $(\mathrm{N})$ was determined through distillation and titration using the micro kjeldahl method (AOAC, 1996). Phosphorus $(\mathrm{P})$ was determined calorimetrically using sodium phenol and ammonium molybdate plus ascorbic acid method (AOAC, 1996). The absorbance was read on the UV Visible Spectrophotometer (Model of spectrophotometer). Calcium $(\mathrm{Ca})$, magnesium $(\mathrm{mg})$, potassium $(\mathrm{K})$, Zinc $(\mathrm{Zn})$ and iron $(\mathrm{Fe})$ was determined by atomic absorption spectrophotometry (Varian SpectrAA 300). Data is expressed as total mineral content in $\mathrm{mg} / \mathrm{g}$ on dry weight basis.

\subsection{Statistical Analysis}

Analysis of variance was performed on the data collected using general linear model (PROC GLM) procedure of Statistical Analysis System (SAS) 2009 program package, version 9.1. Appropriate regression models were used to examine the response of bean seed genotypes to different harvesting times. Multiple comparisons among means was done using Protected Least Significant Difference (LSD) at $p=0.05$. Proc univariate procedure was carried out on residuals to support assumptions of normality made.

\section{Results and Discussion}

Genotype and harvest time had a significant $(\mathrm{P}<0.05)$ effect in the proximate and mineral nutrition of common bean during two seasons of study (Tables 1 and 2). There was significantly $(\mathrm{P}<0.05)$ high dry matter $(94 \%)$, crude fibre (5\%), crude protein (22\%) and ash content (5\%) from genotype DAB 564 than DAB 520 irrespective of season (Table 1). However, proximate nutrition was high during the first season of cultivation compared to season 2 (Table 1). Crude fibre and protein resulted with 17 or $41 \%$ and 6 or $7 \%$ genotypic difference, respectively during season 1 or 2 (Table 1), indicating genetic variations with genotype DAB 564 expressing a better nutrition than DAB 520. DAB 564 may genetically have a high photosynthetic activity and partitioning for mineral composition. The seed ash content ranged between $4-5 \%$ indicating that common bean seed genotypes are an important source of minerals.

Basing on nutritional response towards time of harvest, the lowest and highest crude protein content were $19 \%$ and $22 \%$ from late and early harvest during season 1 or $16 \%$ and $23 \%$ from late and mid harvest during season 
2, respectively (Table 1). However, during the first cultivation early and mid-season harvest did not significantly $(\mathrm{P}<0.05)$ differ (Table 1). In general, mid harvest was consistent in recording the highest seed proximate concentrations even though in some cases there was no significant $(\mathrm{P}<0.05)$ difference between early and midharvest towards crude protein and ash content (Table 1).

This indicates a stronger source-sink relationship during early and mid-stages of harvest which means sufficient accumulation and partitioning of photo assimilates hence high seed protein and ash concentration. Muasya (2001) also found a high seed dry matter from early and medium harvested pods than in late harvest irrespective of cultivar. Cocks (1990) also reported an increased seed quality and dry matter content which was related to an increase in a higher seed filling rate at early/mid stages which was attributed to less competition for accumulating insoluble reserves before all seeds are formed.

Table 1. Effect of genotype and harvest time on proximate content of common bean

\begin{tabular}{|c|c|c|c|c|c|c|c|c|}
\hline & \multicolumn{2}{|c|}{ Dry Matter (\%) } & \multicolumn{2}{|c|}{ Crude Fibre (\%) } & \multicolumn{2}{|c|}{ Crude Protein (\%) } & \multicolumn{2}{|c|}{ Ash Content (\%) } \\
\hline & S1 & $\mathrm{S} 2$ & $\mathrm{~S} 1$ & $\mathrm{~S} 2$ & $\mathrm{~S} 1$ & $\mathrm{~S} 2$ & $\mathrm{~S} 1$ & $\mathrm{~S} 2$ \\
\hline \multicolumn{9}{|l|}{ Genotypes } \\
\hline DAB 564 & $93.70 \mathrm{a}$ & $93.43 \mathrm{a}$ & $5.42 \mathrm{a}$ & $5.38 \mathrm{a}$ & $21.75 \mathrm{a}$ & $19.90 \mathrm{a}$ & $4.72 \mathrm{a}$ & $4.54 \mathrm{a}$ \\
\hline DAB 520 & $93.60 \mathrm{~b}$ & $92.33 b$ & $3.21 \mathrm{~b}$ & $4.48 \mathrm{a}$ & $20.13 b$ & $18.76 \mathrm{~b}$ & $4.61 \mathrm{~b}$ & $3.97 \mathrm{~b}$ \\
\hline LSD & 0.086 & 0.45 & 1.23 & 1.12 & 1.25 & 0.80 & 0.12 & 0.42 \\
\hline Significance & $*$ & $* * *$ & $* *$ & NS & $*$ & $* *$ & $* * * *$ & $* *$ \\
\hline \multicolumn{9}{|l|}{ Harvesting time } \\
\hline Early Harvest & $93.56 b$ & $93.42 \mathrm{a}$ & $2.19 \mathrm{~b}$ & $6.60 \mathrm{a}$ & $21.81 \mathrm{a}$ & $18.89 \mathrm{~b}$ & $4.81 \mathrm{a}$ & $4.21 b$ \\
\hline Mid Harvest & $93.71 \mathrm{a}$ & $93.60 \mathrm{a}$ & $5.33 \mathrm{a}$ & $5.27 \mathrm{a}$ & $21.24 \mathrm{ab}$ & $22.73 \mathrm{a}$ & $4.91 \mathrm{a}$ & $5.29 \mathrm{a}$ \\
\hline Late Harvest & $93.68 \mathrm{a}$ & $91.61 \mathrm{~b}$ & $4.70 \mathrm{a}$ & $2.93 b$ & $19.67 \mathrm{c}$ & $16.38 \mathrm{c}$ & $4.28 b$ & $3.26 \mathrm{c}$ \\
\hline LSD & 0.11 & 0.55 & 1.51 & 1.37 & 1.56 & 0.98 & 0.143 & 0.52 \\
\hline Significance & $*$ & $* * * *$ & $*$ & $* * *$ & $*$ & $* * * *$ & $*$ & $* * * *$ \\
\hline
\end{tabular}

Note. $*, * *, * * *, * * * *$ Significance at $\mathrm{P}=0.05,0.01,0.001,0.0001$, respectively. $\mathrm{NS}=$ Not significant.

Means separated using the Least Significant Difference (LSD) at $\mathrm{P}=0.05$; Means with the same letter(s) are not significantly different.

There was a significant $(\mathrm{P}>0.05)$ effect of genotypes towards all the common bean mineral composition irrespective of season with exception of magnesium during season 1 (Table 2). Comparing genotypes, DAB 564 (white seed) had a high mineral content than DAB 520 (red seed) across seasons (Table 2). In both seasons, iron $(\mathrm{Fe})$ was the most abundant mineral with the lowest and highest values of 53 and $70 \mathrm{mg} \mathrm{g}^{-1}$ from DAB 520 and DAB 564, respectively (Table 2) making a 24\% difference among the two genotypes (Table2). This was similar to the findings by Silva et al. (2012) and McClean et al. (2017). In their findings McClean et al. (2017) observed a high $\mathrm{Fe}$ and $\mathrm{Zn}$ concentrations in small-white $(63 / 33 \mathrm{~g} / \mathrm{g})$ than small red $(57 / 30)$ genotypes with $9 \%(\mathrm{Fe})$ and $10 \%$ (Zn) difference between the genotypes. Silva et al., (2012) also reported a high $\mathrm{Zn}$ and Fe concentrations in the black market bean genotypes.

From the current study potassium $(\mathrm{K})$, calcium $(\mathrm{Ca})$ and phosphorus $(\mathrm{P})$ resulted with 12,19 and 53\% genotype differences in season 1 while during the second cultivation there was $35 \%, 19 \%$ and $22 \%$ difference among genotypes, respectively (Table 2$)$. The significant $(\mathrm{P}<0.05)$ difference among genotypes on micro and macro seed mineral concentration implies that genetic difference of common bean influence its seed nutritional value. The accumulation of mineral elements in the bean seed is influenced by crop growth and development factors which are partially controlled by genes. This has been explained by Conte and Walker (2011) and McClean et al. (2017) that photosynthetic activities are essential for delivery of minerals from the source to the sink tissues (seeds) through the xylem-phloem pathway. This process requires multiple transporters and regulatory pathways such as transcription factors, mRNAs, sugars and hormones specific or shared to a mineral (Lejay et al., 2003; Pottier et al., 2014; Paul et al., 2015). The translocation pathway indicates that genetic components or allelic variation of genes that encode this factors control variability in seed mineral concentrations among genotypes (Ding et al., 2013; Mamidi et al., 2014; Huang et al., 2015). In both seasons the micro and macro mineral elements of calcium $(\mathrm{Ca})$, iron $(\mathrm{Fe})$, potassium $(\mathrm{K})$, phosphorus $(\mathrm{P})$ were significantly $(\mathrm{P}<0.05)$ high in white coloured bean of genotype DAB 564 compared to a red coloured bean of genotype DAB 520 (Table 2). Similar 
findings were reported by Bassett (2007) where the white coloured beans had significantly high $\mathrm{Ca}, \mathrm{Cu}, \mathrm{Fe}, \mathrm{Mg}$, Mn, Mo, Ni, P, S compared to coloured beans.

Table 2. Effect of genotype and harvest time on mineral nutrition of common bean

\begin{tabular}{|c|c|c|c|c|c|c|c|c|c|c|}
\hline & \multicolumn{2}{|c|}{$\begin{array}{l}\text { Calcium }(\mathrm{Ca}) \\
\left(\mathrm{mg} \mathrm{g}^{-1}\right)\end{array}$} & \multicolumn{2}{|c|}{ Iron $(\mathrm{Fe})\left(\mathrm{mg} \mathrm{g}^{-1}\right)$} & \multicolumn{2}{|c|}{$\begin{array}{l}\text { Potassium }(\mathrm{K}) \\
\left(\mathrm{mg} \mathrm{g}^{-1}\right)\end{array}$} & \multicolumn{2}{|c|}{$\begin{array}{c}\text { Phosphorus (P) } \\
\left(\mathrm{mg} \mathrm{g}^{-1}\right)\end{array}$} & \multicolumn{2}{|c|}{$\begin{array}{c}\text { Magnesium (Mg) } \\
\left(\mathrm{mg} \mathrm{g}^{-1}\right)\end{array}$} \\
\hline & $\mathrm{S} 1$ & $\mathrm{~S} 2$ & $\mathrm{~S} 1$ & $\mathrm{~S} 2$ & $\mathrm{~S} 1$ & $\mathrm{~S} 2$ & $\mathrm{~S} 1$ & $\mathrm{~S} 2$ & $\mathrm{~S} 1$ & $\mathrm{~S} 2$ \\
\hline \multicolumn{11}{|l|}{ Genotypes } \\
\hline DAB 564 & $0.38 \mathrm{a}$ & $0.36 \mathrm{a}$ & $70.18 \mathrm{a}$ & $73.12 \mathrm{a}$ & $1.86 \mathrm{a}$ & $2.76 \mathrm{a}$ & $0.16 \mathrm{a}$ & $0.21 \mathrm{a}$ & $0.20 \mathrm{a}$ & $0.23 \mathrm{a}$ \\
\hline DAB 520 & $0.18 \mathrm{~b}$ & $0.28 \mathrm{~b}$ & $52.83 b$ & $67.01 \mathrm{~b}$ & $1.64 \mathrm{~b}$ & $1.80 \mathrm{~b}$ & $0.13 b$ & $0.17 b$ & $0.19 \mathrm{a}$ & $0.18 \mathrm{~b}$ \\
\hline Significance & $*$ & $* *$ & * & * & * & $* *$ & $*$ & $*$ & NS & $* * * *$ \\
\hline LSD & 0.19 & 0.05 & 15.99 & 6.10 & 0.22 & 0.48 & 0.03 & 0.03 & 0.21 & 0.01 \\
\hline \multicolumn{11}{|c|}{ Harvesting Time } \\
\hline Early Harvest & $0.23 \mathrm{a}$ & $0.40 \mathrm{a}$ & $100.58 \mathrm{a}$ & $73.36 \mathrm{~b}$ & $2.01 \mathrm{a}$ & $3.05 \mathrm{a}$ & $0.21 \mathrm{a}$ & $0.18 b$ & $0.19 b$ & $0.21 b$ \\
\hline Mid Harvest & $0.23 \mathrm{a}$ & $0.37 \mathrm{a}$ & $79.18 b$ & $83.85 \mathrm{a}$ & $1.73 b$ & $2.27 \mathrm{~b}$ & $0.16 b$ & $0.25 \mathrm{a}$ & $0.21 \mathrm{a}$ & $0.23 \mathrm{a}$ \\
\hline Late Harvest & $0.21 b$ & $0.20 \mathrm{~b}$ & $32.75 c$ & $49.99 \mathrm{c}$ & $1.63 b$ & $1.52 \mathrm{c}$ & $0.08 \mathrm{c}$ & $0.14 b$ & $0.19 b$ & $0.19 \mathrm{c}$ \\
\hline Significance & $*$ & $* * *$ & $* * *$ & $* * * *$ & $*$ & $* * *$ & $* * *$ & $* * *$ & $* *$ & $* * *$ \\
\hline LSD & 0.02 & 0.06 & 19.59 & 7.49 & 0.27 & 0.58 & 0.04 & 0.04 & 0.01 & 0.02 \\
\hline
\end{tabular}

Note. $* * *, * * *, * * * *$ Significance at $\mathrm{P}=0.05,0.01,0.001,0.0001$, respectively. NS = Not significant.

Means separated using the Least Significant Difference (LSD) at $\mathrm{P}=0.05$; Means with the same letter(s) are not significantly different; S means Season.

In their findings seed mineral concentration as affected by bean genotypes was genetically controlled by phenotypic difference of colour from a single gene $p$, all coloured common bean genotypes were found to carry a dominant allele while all white genotypes carried the recessive $p$ allele (Bassett, 2007). This was emphasised by Possobom et al. (2015) and McClean et al. (2002) who studied common bean seed coat and found that colour expression depends on multiple allelles at $P$ locus. This genes $(V$ or $v v)$ regulate flavanols $(V)$ and anthocyanin (vv) biosynthetic pathways (Bassett, 2007; Binger et al., 2000).

There was a significantly $(\mathrm{P}<0.05)$ high seed mineral composition when common bean was harvested early compared to late harvest of season 1 except for magnesium. During season 2, the highest seed mineral concentration were produced during mid than early or late harvest with an exception of potassium (Table 2). However, ca, $\mathrm{K}$ and $\mathrm{mg}$ bean concentrations experienced a similar response at early or mid-harvest irrespective

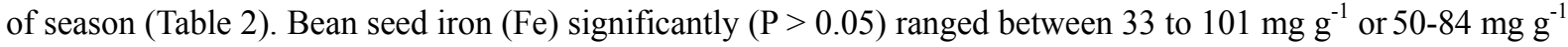
as affected by the time of harvest during the first or second season, with the highest fe value at early or late harvest recording 40-68\% nutritional difference among harvesting stages, respectively (Table 2). Early pods benefit from high influx of assimilate when the plant switches from vegetative to reproductive phase (Bewley $\&$ Black, 1994). Dornbros Jr. (1995) stated that the earlier the crop is harvested after reaching physiological maturity the better the seed quality. The decrease in mineral seed concentration late during harvest may be explained by a loss in seed quality parameters most of which impact on mineral nutrition. Dornbros Jr. (1995) has reported that after physiological maturity drying begins, triggered by senescence where the seed quality is gradually lost after physiological maturity as the natural seed deterioration progresses. The shorter the period between physiological and harvest maturity, the less seed deterioration rate (Muasya, 2001) and therefore greater seed quality.

Genotype did not significantly $(\mathrm{P}>0.05)$ influence the zinc content of common bean seed however, harvesting time significantly $(\mathrm{P}<0.05)$ influenced zinc concentrations across seasons (Table 3$)$. There was significantly high zinc value when bean seeds were harvested early or mid during season 1 or 2 respectively (Table 3 ). In both seasons the lowest zinc content was produced late during the season (Table3). Season 1 further revealed a significant interaction $(\mathrm{P}<0.05)$ between genotype and harvest time to influence zinc content of common bean, resulting with a range between $41-45 \mathrm{mg} \mathrm{g}^{-1}$ (Table 3). The lowest zinc content was $41 \mathrm{mg} \mathrm{g}^{-1}$ from DAB 564 late in the season, however it did not significantly $(\mathrm{P}>0.05)$ differ with any genotype at any time of harvest except for DAB 564 at early harvest (Table 3). The low zinc content during late harvest of both genotypes may be influenced by senescence interrupting seed filling process of late pods due to the reduced photosynthetic 
activities. Wortmann (2006) stated that late harvest during the season could expose seeds to unfavourable conditions resulting in deterioration in seed quality and nutrition, this was also supported by Dornbos Jr. (1995) who reported that after physiological maturity, drying commences and seed quality is gradually lost.

Table 3. Effect of genotype and harvest time on zinc content of common bean

\begin{tabular}{|c|c|c|c|c|c|}
\hline \multicolumn{3}{|c|}{ Genotype or Harvest time Effect } & \multicolumn{3}{|c|}{ Genotype $\times$ Harvest time Interaction Effect } \\
\hline & \multirow{2}{*}{ Season 1} & \multirow{2}{*}{ Season 2} & \multirow{2}{*}{ Genotypes } & \multicolumn{2}{|c|}{ Harvesting Time } \\
\hline & & & & Season1 & Season2 \\
\hline Genotypes & & & Early-Harvest & & \\
\hline DAB 564 & $43.14 \mathrm{a}$ & $37.73 \mathrm{a}$ & DAB 564 & $45.38 \mathrm{a}$ & $42.93 \mathrm{ab}$ \\
\hline DAB 520 & $42.40 \mathrm{a}$ & $34.10 \mathrm{a}$ & DAB 520 & $42.08 \mathrm{bc}$ & $38.77 \mathrm{~b}$ \\
\hline Significance & $\mathrm{NS}$ & $\mathrm{NS}$ & Mid-Harvest & & \\
\hline LSD & 0.23 & 3.47 & DAB 564 & $42.71 b c$ & $45.53 \mathrm{a}$ \\
\hline Harvesting time & & & DAB 520 & $42.97 \mathrm{~b}$ & $44.34 \mathrm{ab}$ \\
\hline Early-Harvest & $43.73 \mathrm{a}$ & $40.85 \mathrm{~b}$ & Late-Harvest & & \\
\hline Mid-Harvest & $42.84 b$ & $44.94 \mathrm{a}$ & DAB 564 & $41.33 \mathrm{c}$ & $24.75 \mathrm{c}$ \\
\hline Late-Harvest & $41.73 \mathrm{c}$ & $21.98 \mathrm{c}$ & DAB 520 & $42.14 \mathrm{c}$ & $19.20 \mathrm{c}$ \\
\hline Significance & $* *$ & $* * * *$ & Significance & ** & NS \\
\hline LSD & 0.20 & 4.60 & LSD & 0.99 & 1.88 \\
\hline
\end{tabular}

Note. ${ }^{* *}, * * * *$ Significance at $\mathrm{P}=0.01,0.0001$, respectively. $\mathrm{NS}=$ Not significant.

Means separated using the Least Significant Difference (LSD) at $\mathrm{P}=0.05$; Means with the same letter(s) are not significantly different.

The study indicates that common bean has a sufficient seed mineral content with crude protein, iron and zinc as the abundant proximate and mineral concentrations irrespective of genotype or harvest time. The range between $20-22 \%$ crude protein content of bean seed makes it a sufficient protein source for the genotypes studied at any stage of harvest. Pearson (1976) has reported that plant foods should contain more than $12 \%$ of its caloric value as a good protein source while the Food and Nutrition Board of Institute of Medicine (2002) reported a daily required intake of crude protein ranging between $9-13 \mathrm{~g}$ and 34-56 $\mathrm{g}$ for children and adults, respectively. The type of protein contained in beans is reported to be highly digestible for human consumption (Demardi-Blacberry et al., 2004), hence a good source for protein malnutrition. Basing on iron and zinc content, food commodity is regarded a nutrient source for human consumption when $100 \mathrm{~g}$ of the product has more than $15 \%$ dietary reference intake (DRI) for the desired nutrient. Also DRI for iron and zinc is $14 \mathrm{mg} /$ day and 15 $\mathrm{mg}$ /day respectively (Codex Alimentarious Commission/FAO, 1997). From the current study, findings reveal that common bean genotypes DAB 520 and DAB 564 produced fe (41-45 mg g $\left.{ }^{-1}\right)$ and zn (33-103 mg g $\left.\mathrm{g}^{-1}\right)$ content with 3 or 7 times daily recommended intake at all harvesting stages hence it can be considered as a high $\mathrm{Fe}$ and Zn source (Carvalho et al., 2011). Iron and zinc are recommended as essential for proper functioning of the immune system and some human health deficiencies such as anemia (Barclay et al., 1996; Rosado et al., 1992). Also, Rayman (2000), and Tugce et al. (2018) reported a positive correlation $\left(\mathrm{r}=0541^{* *}\right)$ between zinc and selenium content, this is an important nutritional element for strengthening immune system and lowering the risk of cancer (Rayman, 2000; Sunde, 1997; Tugce et al., 2018) and HIV/AIDS, a disease known to lower the immune system (Maruapula \& Novakofski, 2010). Low incidences of cardiovascular diseases, cholesterol, diabetes and obesity has been related with high bean consumption (Demardi-Blacberry et al., 2004; Schneider, 2002; Suarez-Martinez et al., 2015).

\section{Conclusion}

Proximate and mineral nutrition of common bean is significantly influenced by genotype and harvesting time. Common bean genotypes had the highest proximate and mineral ( $\mathrm{Ca}, \mathrm{Fe}, \mathrm{K}, \mathrm{P}, \mathrm{Zn})$ seed concentrations during early or mid-harvest compared to a later stage. Genotype DAB 564 is highly nutritive compared to DAB 520 . However, the two common bean genotypes studied had sufficient nutrients with crude protein, $\mathrm{Fe}$ and $\mathrm{Zn}$ as the most abundant ranging up to $22 \%, 45 \mathrm{mg} \mathrm{g}^{-1}$ and $103 \mathrm{mg} \mathrm{g}^{-1}$, respectively. The nutritional importance of common bean genotypes DAB 564 and DAB 520 in this study proves that enhancing cultivation of common bean in Botswana will not only promote food security but improve household diets and human health nutrition of 
different age and health groups meeting their daily key nutritional requirements. The high iron and zinc levels implies that as a plant based mineral source, common bean genotype DAB 564 has a potential for use in food biofortification to enhance $\mathrm{Fe}$ and $\mathrm{Zn}$ accumulation especially for infant formulations (such as Tsabana-a meal issued as supplementary diet in health facilities of Botswana).

\section{Acknowledgements}

The authors would like to acknowledge Ministry of Agricultural Development and Food Security, CIAT-PABRA for funding bean project.

\section{References}

AOAC (Association of Official Analytical Chemists). (1990). Official Methods of Analysis of AOAC (15th ed.). Washington, D.C. USA.

AOAC (Association of Official Analytical Chemists). (1996). Official Methods of Analysis of AOAC (17th ed.). Arlington, Virginia, USA.

AOAC (Association of Official Analytical Chemists). (2012). Official Methods of Analysis of AOAC International (19th ed.). Maryland, USA.

Barclay, D. V., Heredia, L., Gil-Ramos, J., Montalvo, M. M., Lozano, R., Mena, M., \& Dirren, H. (1996). Nutritional status of institutionalized elderly in Ecuador. Arch Latinoam Nutrition, 46(2), 122-127.

Bassett, M. J. (2007). Genetics seed coat color and pattern in common bean. Plant Breeding Reviews, 28, 239-315. https://doi.org/10.1002/9780470168028.ch8

Beebe, S., Gonzalez, A. V., \& Rengifo, J. (2000). Research on trace minerals in the common bean. Food Nutrition Bulletin, 21, 387-391. https://doi.org/10.1177/156482650002100408

Bekker, R. P., \& De Wit, P. V. (1990). Explanatory note on the land systems map of Botswana. Soil mapping and advisory services project (Field Document 31, p. 43). FAO/UNDP/Government of Botswana. Retrieved from http://library.wur.nl

Beninger, C. W., Hosfield, G. L., Basset, M. J., \& Owens, S. (2000). Chemical and morphological expression of the B and Asp seed coat genes in Phaseolus vulgaris L. Journal of American Society of Horticultural Science, 125, 52-58. https://doi.org/10.21273/JASHS.125.1.52

Bewley, J. D., \& Black, M. (1994). Seeds: Physiology of development and germination (2nd ed., pp. 1-33). New York, Plenum Press. https://doi.org/10.1007/978-1-4899-1002-8_1

Carvalho, L. M. J., Correa, M. M., Pereira, E. J., Nutti, M. R., Carvalho, L. V., Ribeiro, M. G., \& Freitas, S. C. (2011). Iron and zinc retention in common beans (Phaseolus vulgaris L.) after home cooking. Food Nutrition Research, 56, 15618. https://doi.org/103402/mp/661015618

Cerna, J., \& Beaver, J. S. (1989). A visual indicator of the physiological maturity of indeterminate dry beans. The Journal of Agriculture of the Puerto Rico, 73(4), 361-365. https://doi.org/10.46429/jaupr.v73i4.6314

Cocks, P. S. (1990). Dynamics of flower and pod production in annual medics (Medicago spp.). I. Spaced plants. Australian Journal Agricultural Research, 41, 911-921. https://doi.org/10.1071/AR9900911

Codex Alimentarius Commission. (1997). Guidelines for use of nutrition claims (FAO/WHO Food Standards Program, CAC/GL 23 1997, 2004 ed.).Rome: FAO.

Conte, S. S., \& Walker, E. L. (2011). Transporters contributing to iron trafficking in plants. Molecular Plant, 4, 464-476. https://doi.org/10.1093/mp/ssr015

Copeland, L. O., \& McDonald, B. M. (1995). Principles of seed science and technology (p. 446). Chapman and Hall, New York.

Dermardi-Blacberry, I., Wahiliquist, M., Kouris-Blazos, A., Steen, B., Lukito, W., \& Horiek, H. (2004). Legumes, the most predictor of survival in older people of different ethnicities. Asia Pacific Journal of Nutrition, 13(2), 217-220.

Dharmalingam, C., \& Basu, R. N. (1990). Seed development and maturation studies in mungbean. Seed Research, 18, 1-6.

Ding, G., Shi, L., Zhao, H., Cai, K., Liu, K., \& Xu, F. (2013). Genetic analysis of seed mineral accumulation affected by phosphorus deprivation in Brassica napus. Euphytica, 193(2), 251-264. https://doi.org/10.1007/ s10681-031-0933-z 
Dornbos Jr., D. L. (1995). Production environment and seed quality. In A. S. Basra (Ed.), Basic mechanisms and agricultural implications (pp. 119-145). Food Products Press, London. https://oi.org/10.1201/ 9781003075226-4

FAOSTAT. (2010). Food and Agricultural Commodities Production. Retrieved from https://faostat .fao.org

Food and Nutrition Board of Institute of Medicine. (2002). Dietary reference intake for energy, carbohydrate, fibre, fat, fatty acids, cholesterol, protein and amino acids (micronutrients). National Academy of Sciences. Retrieved from https://www.nap.edu

Huang, Y., Sun, C., Min, J., Chen, Y., Tong, C., \& Bao, J. (2015). Association mapping of quantitative trait loci for mineral element contents in whole grain rice (Oryza sativa L.). Journal of Agriculture Food Chemistry, 63, 10892-10892. https://doi.org/10.1021/acs.jafc.5b04932

Jones A. L. (1999). In D. Mejia \& B. Lewis (Eds.), Phaseolus Bean: Post-harvest Operations (p. 22). Centro Internacional de Agricultura Tropical (CIAT). Retrieved from https://www.cgiar.org/ciat

Kelly, A. F. (1988). Seed production of agricultural crops. Longman Scientific and Technical, Essex.

Kelly, J. F., \& Scott, M. K. (1992). The nutritional value of snap beans versus other vegetables. In G. Henry \& W. Jansen (Eds.), CIAT Proceedings of an International Conference on Snap Beans in the Developing World Held from $16^{\text {th }}$ to $20^{\text {th }}$ October 1989 in Cali, Columbia (pp. 23-46).

Lejay, L., Gansel, X., Cerezo M., Tillard, P., Muller, C., \& Krapp, A. (2003). Regulation of root ion transporters by photosynthesis: Functional importance and relation with hexokinase. Plant Cell, 15, 2218-2232. https://doi.org/10.1105/tpc.013516

Mamidi, S., Lee, R. K., Goos, J. R., \& McClean, P. E. (2014). Genome-wide association studies identifies seven major regions responsible for iron deficiency chlorosis in soybean (Glycine max). PloS One, 9, e107469. https://doi.org/10.1371/journal.Pone.0107469

Maruapula, S. D., \& Novakofski, C. K. (2010). Nutrient Intake and adequacy of Batswana elderly. African Journal Food Agriculture Nutrition and Development, 10(7), 1-20. https://doi.org/10.4314/ajfand.v10i7. 59025

McClean, P. E., Lee, R. K., Otto, C., Gepts, P., \& Bassett, M. J. (2002). Molecular and phenotypic mapping of genes controlling seed coat pattern and colour in common bean (Phaseolus vulgaris L.). The Journal of Heridity, 93(2), 148-152. https://doi.org.10.1093/jhered/93.2.148

McClean, P. E., Moghaddam, S. M., Lopez-Millan, A.-F., Brick, M. A., Kelly, J. D., Miklas, P. N., ... Grusak, M. A. (2017). Phenotypic diversity for seed mineral concentration in North American dry bean germplasm of middle American ancestry. Panhandle Research and Extension Center, 105. https://oi.org/10.2135/ cropsci2017.04.0244

Molosiwa, O. O., Pharudi, J., Seketeme, S., Mashiqa, P., \& Chirwa, R. (2019). Assessing yield stability and adaptability of Andean common bean genotypes in the semi-arid environment of Botswana. African Journal of Agricultural Research, 14(32), 1593-1600. https://doi.org/10.5897/AJAR2019.13988

Muasya, R. M. (2001). Crop physiological analysis of seed quality variation in common bean (Phaseolus vulgaris L.) (PhD Thesis, Wageningen University, Holland).

Ndengwa, A. M., Muchui, M. N., Wachiuri, S. M., \& Kimamira, J. N. (2006). Evaluation of snap bean varieties for adaptability and pod quality. Proceedings of the $10^{\text {th }} H Q s, 13^{\text {th }}-17^{\text {th }}$ Nov, 2006, Nairobi, Kenya.

Ndidi, C. U., Olagunju, A., Muhammad, A., Billy, F, G., \& Okpe, O. (2014). proximate, antinutritional and mineral composition of raw and processed (boiled and roasted) Sphenostylis stenocarpa seeds from Southern Kaduna, Northwest Nigeria. International Scholarly Research Notices in Nutrition, 2014, Article ID 280837. https://doi.org/10.1155/2014/280837

Nestel, P., Bouis, H. E., Meenakshi, J. V., \& Pfeiffer, W. (2006). Biofortification of staple food crops. Journal of Nutrition, 136(4), 1064-1067. https://doi.org/10.1093/jn/136.4.1064

Paul, S., Datta, S. K., \& Datta, K. (2015). mRNA regulation of nutrient homeostasis in plants. Frontier in Plant Science, 6, 232. https://doi.org/10.3389/fpls.2015.00232

Pearson, D. (1976). Chemical analysis offoods (7th ed.). London: Churchill. Retrieved from https://www.scip.org

Petry, N., Boy, E., Wirth, J. P., \& Hurrel, R. F. (2015). The potential of the common bean (Phaseolus vulgaris) as a vehicle for iron biofortification. Nutrients, 7, 1144-1173. https://doi.org/10.3390/nu7021144 
Possobom, M. T. D. F., Ribeiro, N. D., \& Zemolin, A. E. M. (2015). Genetic control of seed coatcolour of Middle American and Adean bean seeds. Genetica, 143, 45-54. https://doi.org/10.1007/s10709.014-9811-4

Pottier, M., Masclaux-Daubresse, C., Yoshimoto, K., \& Thomine, S. (2014). Autophagy as a possible mechanism for micro nutrient remobilization from leaves to seeds. Frontier in Plant Science, 5, 11. https://doi.org/ 10.3389/fpls.2014.00011

Rayman, M. P. (2000). The importance of selenium to human health. Lacent, 15-356(9225), 233-241. https://doi.org/10.1016/s0140-6736(00)02490-9

Richardson, K. V. A. (2012). Evaluation of six fresh green bean varieties for pod quality and yield. Gladstone Road Agricultural Centre Crop Research Report, 9, 1-8.

Rosado, J. L., Loapez, P., Morales, M., Munaoz, E., \& Allen, L. H. (1992). Bioavailability of energy, nitrogen, fat, zinc, iron and calcium from rural and urban Mexican diets. British Journal of Nutrition, 68, 45-58. https://doi.org/10.1079/BJN19920065

Schierri, R., Castro, J. F. G., \& Moura, A. S. (2003). Factors associated with dietary patterns in the urban Brazilian population. Cadernos de Saude Publica, 19, 47-53. https://doi.org/10.1590/S0102-311X200 3000700006

Schneider, A. V. (2002). Overview of the market and consumption of pulses in Europe. British Journal of Nutrition, 88, s243-250. https://doi.org/10.1079/2002713

Silva, C. A., Abreu, A. D. F. B., Ramalho, M. A. P., \& Maia, L. G. S. (2012). Chemical composition as related to seed colour of common bean. Crop Breeding and Applied Biotechnology, 12, 132-137. https://doi.org/ $10.1590 /$ S1984-70332012000200006

Suarez-Martinez, S. E., Ferriz-Martinez, R. A., Compos-Vega, R., Elton-Puente, J. E., Karina, de la T. C., \& Garcia-Gasca, T. (2016). Bean Seeds: Leading nutraceutical source for human health. Cyta-Journal of Food, 14(1), 131-137. https://doi.org/10.1080/19476337.2015.1063548

Sunde, R. A. (1997). Selenium. In B. L. O’Dell \& R. A. Sunde (Eds.), Handbook of nutritionally essential mineral elements (pp. 493-556). Marcel Dekker Inc, New York, NY, USA.

Tekrony, D. M., \& Egli, D. B. (1997). Accumulation of seed vigour during development and maturation. In R. H. Ellis, M. Black, A. J. Murdon \& T. D. Hong (Eds.), Basic and Applied Aspects of Seed Biology (pp. 369-384). Kluwer Academic Publishers, Dordrecht. https://doi.org/10.1007/978-94-011-5716-2_41

Tryphone, M. G., \& Nchimbi-Msolla, S. (2010). The effects of the environment on Iron and Zinc concentrations and performance of common bean (Phaseolus vulgaris L.) genotypes. Asian Journal of Plant Sciences, 9, 455-462. https://doi.org/10.3923/ajps.2010.455.462

Tugce, C., Sari, H., Canci, H., Sari, D., Adak, A., Eker, T., \& Toker, C. (2018). The nutritional content of common bean (Phaseolus vulgaris L.) landraces in comparison to modern varieties. Agronomy, 8, 166. https://doi.org/10.3390/agronomy8090166

UNICEF. (2004). Vitamins and mineral deficiencies: A global progress report. S.I: UNICEF. New York.

UNICEF. (2009). State of world's children. Newyork.

van de Venter, H. A., Demir, I., de Meillon, S., \& Loubser, W. A. (1996). Seed development and maturation in edible dry bean (Phaseolus vulgaris L.). South African Journal of Plant and Soil, 13, 47-50. https://doi.org/10.1080/02571862.1996.10634374

World Bank. (2009). World development indicators. S.I: World Bank.

Wortmann, C. S. (2006). Phaseolus vulgaris L. (Common Bean). Prota: Cereals and Pulses. Retrieved from https://database.prota.org

\section{Copyrights}

Copyright for this article is retained by the author(s), with first publication rights granted to the journal.

This is an open-access article distributed under the terms and conditions of the Creative Commons Attribution license (http://creativecommons.org/licenses/by/4.0/). 